\section{University of New Hampshire}

Carsey School of Public Policy
CARSEY RESEARCH

National Issue Brief \#75

\title{
Families Continue to Rely on Wives As Breadwinners Post-Recession
}

\section{An Analysis by State and Place Type}

\author{
Kristin Smith and Andrew Schaefer
}

$\mathrm{T}$ The negative outcomes of the Great Recession have been multifaceted, affecting many areas of family economic well-being. The U.S. economy lost 8.7 million jobs between December 2007 and January 2010. ${ }^{1}$ Although the recession officially ended in June 2009, the national unemployment rate remains approximately 1.5 percentage points higher than the pre-recession rate, even though the total number of jobs lost during the recession has been recovered. ${ }^{2}$ Similarly, long-term unemployment is prevalent, with length of unemployment averaging 37.1 weeks. ${ }^{3}$ Furthermore, involuntary part-time work increased during the recession and has remained relatively constant. ${ }^{4}$ These statistics translate into continued hardship for many Americans, exemplified in the decline in median household income since the onset of the Great Recession. ${ }^{5}$

The recession affected men's employment more than women's, with 69 percent of the jobs that were lost being held by men. ${ }^{6}$ Overall unemployment reached a high of 10.0 percent in October 2009, with men's unemployment at 11.2 percent and women's at 8.7 percent. The unemployment rate has slowly declined during the recovery and was down to 6.4 percent for men and 6.2 percent for women in June 2014. ${ }^{7}$ Married-couple families have responded to husbands' job loss with an increased dependence on wives' earnings. Research on the Great Recession shows that wives whose husbands stopped working were more likely to enter the labor force and, among wives already employed, more likely to increase their hours working for pay. ${ }^{8}$ Despite increased employment among wives with husbands who experienced job loss, overall wives' employment decreased during the Great Recession from 72 percent in 2007 to 71 percent in 2009 and decreased to 69 percent in 2012. The Great Recession affected some areas of the United States more

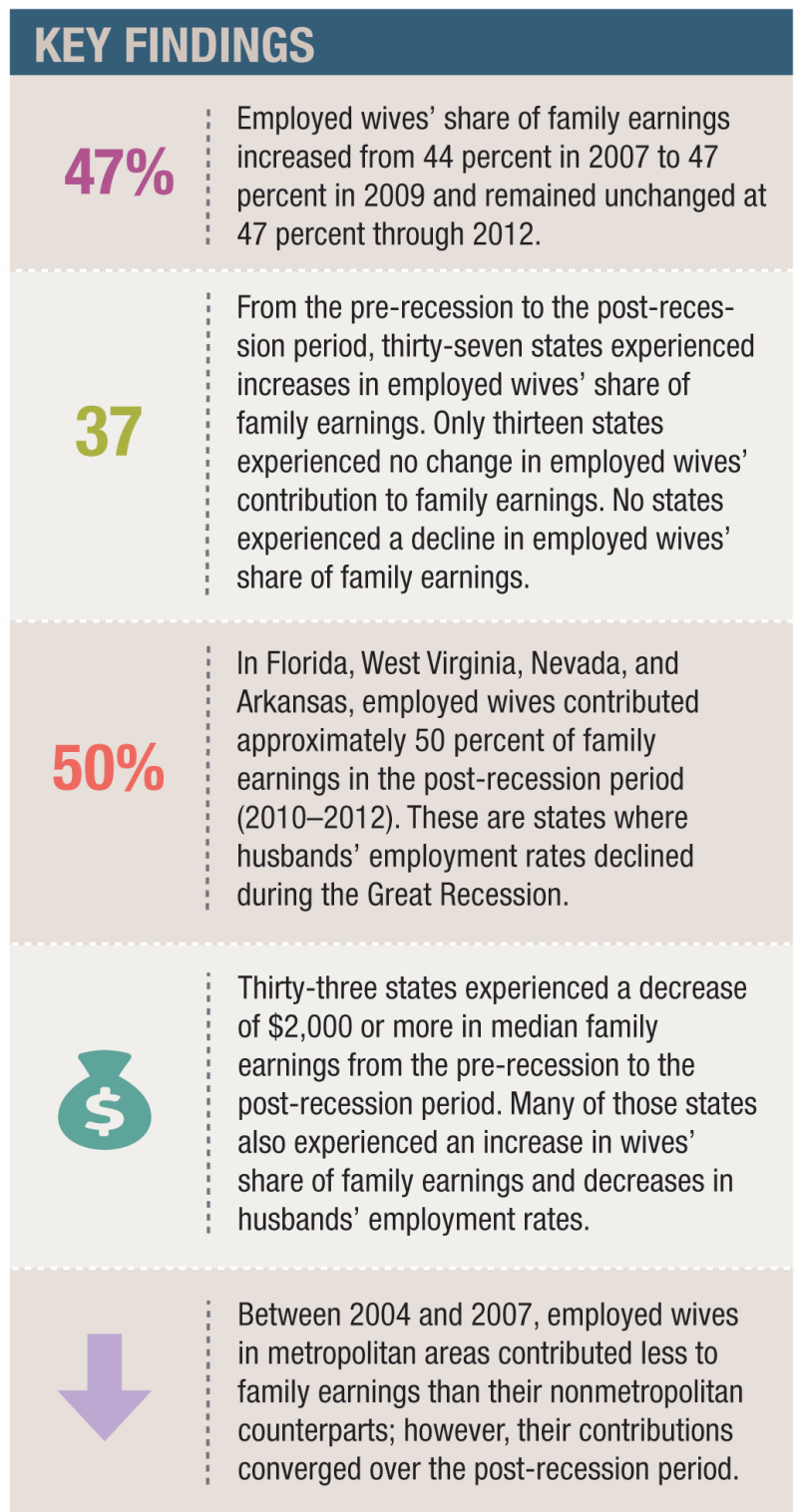

Employed wives' share of family earnings in 2007 to 47 percent in 2009 and remained unchanged at

From the pre-recession to the post-recession period, thirty-seven states experienced increases in employed wives' share of family earnings. Only thirteen states experienced no change in employed wives' contribution to family earnings. No states experienced a decline in employed wives' share of family earnings.

In Florida, West Virginia, Nevada, and Arkansas, employed wives contributed approximately 50 percent of family earnings in the post-recession period (2010-2012). These are states where husbands' employment rates declined during the Great Recession.

Thirty-three states experienced a decrease of $\$ 2,000$ or more in median family earnings from the pre-recession to the post-recession period. Many of those states also experienced an increase in wives' share of family earnings and decreases in husbands' employment rates.

Between 2004 and 2007, employed wives in metropolitan areas contributed less to family earnings than their nonmetropolitan converged over the post-recession period. 


\section{Box 1: Defining Earnings} and Employment

Personal earnings: Sum of annual income from wages and salary, personal farming income, and self-employment.

Family earnings: Sum of husbands' and wives' personal earnings.

Wives' contribution: Wives' personal earnings as a proportion of family earnings.

Employment: Wives and husbands are considered employed if they were working and had positive personal earnings.

than others, and recovery has varied by place as well. This brief presents an analysis of the increased role employed wives played in family economic stability prior to, during, and after the Great Recession, focusing on changes in the contribution of employed wives' earnings to family earnings by state, region, metropolitan areas, and nonmetro residence.

\section{Increased Reliance on Employed Wives' Earnings During Recessions}

One outcome of the Great Recession has been that families rely more on employed wives' earnings. As husbands lose their jobs and family earnings plummet, wives' earnings often keep families afloat. In 2007, immediately prior to the Great Recession, employed wives (those with positive earnings) contributed 44 percent of family earnings. During the recession, their share of family earnings increased by 3 percentage points, to 47 percent by 2009 , a statistically significant increase. Employed wives' share remained at 47 percent through 2012 (see Figure 1). This statistic is not surprising given the slow job recovery and continued high unemployment rates among men. The Great Recession affected families with children younger than 18 as well as employed mothers' contribution to family earnings increased during the Great Recession and has remained at an elevated level since. Even among all wives, which includes those without earnings, we see an increase in their contribution to family earnings from 34 percent in 2007 to 36 percent in 2009, and it has remained steady through 2012 (data not shown).

Figure 1 illustrates how recessions, and in particular the Great Recession, accelerate the trend of families' increased reliance on employed wives' earnings. From 1988 to 2012, employed wives' share of family earnings increased by 9 percentage points. In all three recessions during that period, ${ }^{9}$ annual increases in employed wives' share increased substantially, and the increases were statistically significant. However, the largest singleyear increase occurred during the Great Recession, from 2008 to 2009, when employed wives' contributions increased by 2 percentage points.

Previous research shows that wives' contributions to family earnings are highly sensitive to changes in one or both of the partners' employment status, hours worked, and earnings. ${ }^{10}$ Because recessions are times of economic upheaval and job loss, it is not surprising to see fluctuations in employed wives' contribution to family earnings during recessions. In addition, employed wives' share of family earnings typically remain at an elevated level post-recession even after jobs have returned and men's employment rates return to pre-recession levels. ${ }^{11}$ Thus, recessions may accelerate the

\section{FIGURE 1: EMPLOYED WIVES' CONTRIBUTION TO FAMILY EARNINGS, 1988-2012}

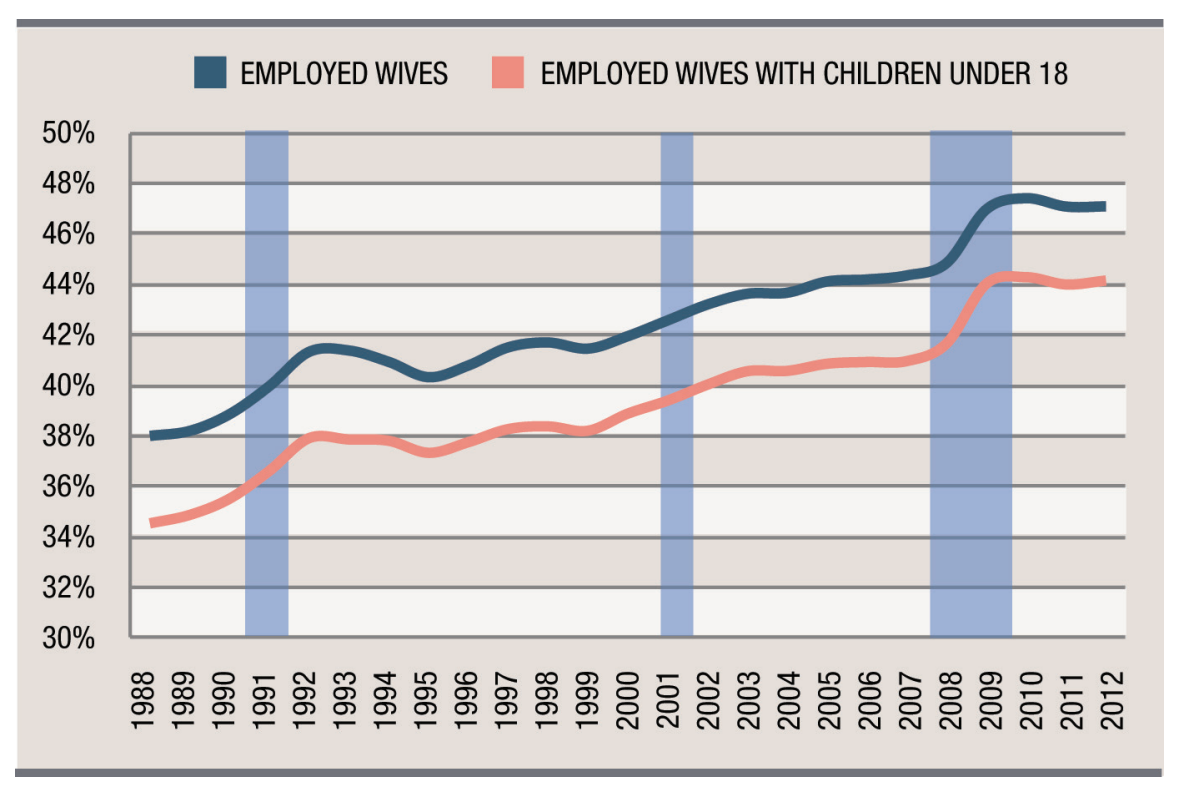

Notes: 1) Wives are between 18 and 64 years of age. 2) The blue bands indicate economic recessions. Source: Current Population Survey: ASEC, 1989-2013 
longer-term trend of increased reliance on wives as breadwinners.

This same trend of a steady increase in wives' contribution to family earnings, with accelerated increases during recessions, is also evident (although consistently 3 to 4 percentage points lower) among all employed wives with children younger than 18 (see Figure 1). In the following sections, we examine employed wives' contribution to family earnings for smaller geographic areas. For some analyses, we combine three years of data for each recession period to have reliable estimates. Thus, we used 2004 to 2006 data for the pre-recession period, 2007 to 2009 data for the recession period, and 2010 to 2012 data for the post-recession period.

\section{Wives as Breadwinners by State}

Figure 2 shows employed wives' contribution to family earnings by state for the post-recession period. In Florida and West Virginia, employed wives contributed approximately one-half of family earnings. In contrast, employed wives in Wyoming and Utah contributed approximately 41 percent to family earnings. Other states, such as Illinois and Rhode Island, were close to the national average of 47 percent.

One possible explanation for these differences may relate to husbands' employment rates. Employed wives living in states with lower employment among husbands tended to contribute more to family earnings, as is the case in Florida, West Virginia, Nevada, and Arkansas. There, employed wives contributed approximately 50 percent of family earnings in the post-recession period and husbands' employment was depressed (see Table 1 on the next page). In contrast, employed wives in Utah contributed approximately 41 percent of family earnings, owing to the combination of a high employment rate (93 percent) among husbands and a low rate (56 percent) of full-time employment among employed wives. North Dakota and Wyoming also have high rates of employment among husbands, which correspond with low contributions of employed wives' share of family earnings.

\section{FIGURE 2: EMPLOYED WIVES' CONTRIBUTION TO FAMILY EARNINGS BY STATE, 2010-2012}

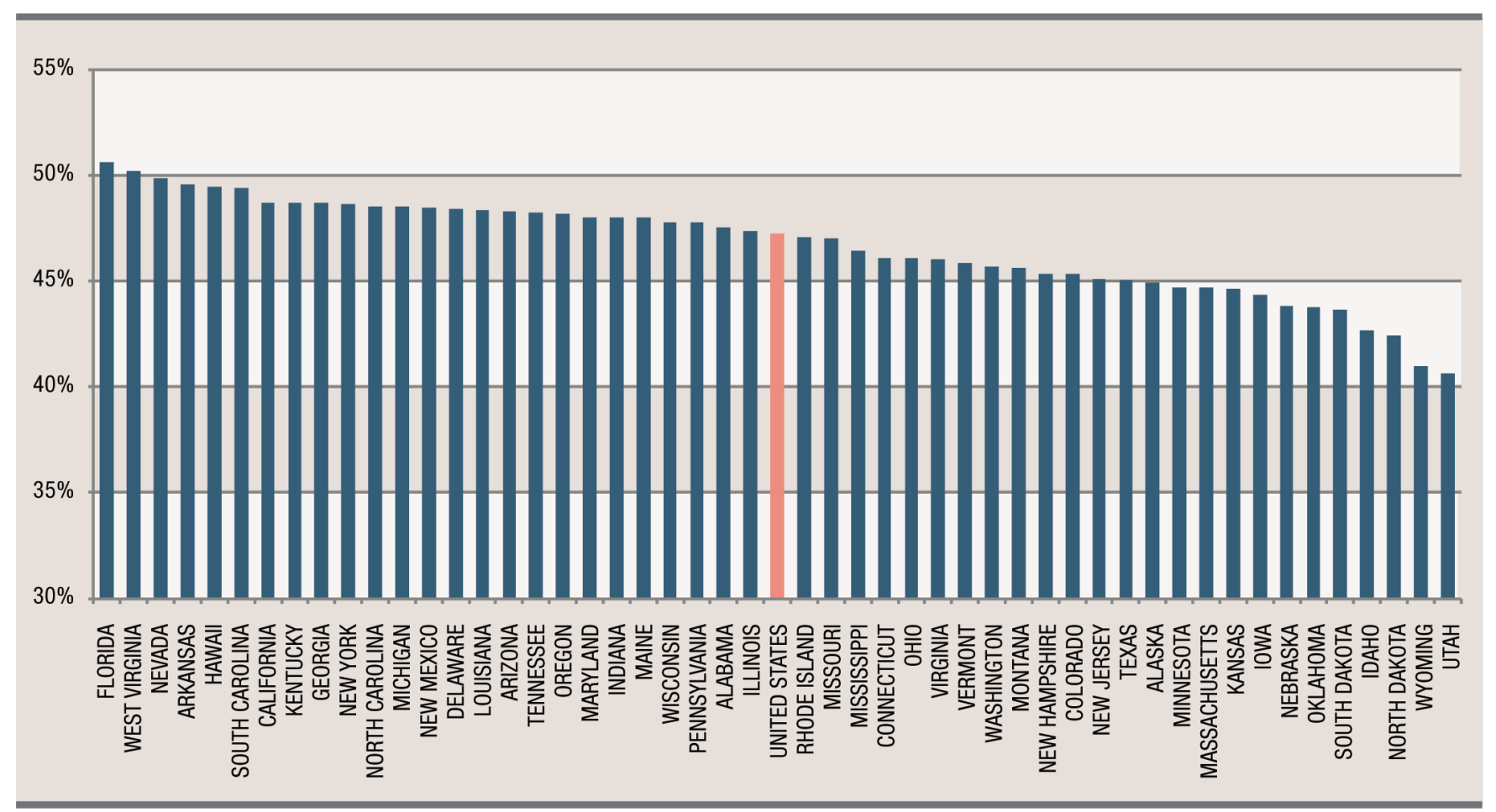

Note: Wives are between 18 and 64 years of age; Washington, DC is excluded from this figure and presented in Figures 8 and 9 in comparison to other metropolitan areas. Source: Current Population Survey: ASEC, 2011-2013 


\section{TABLE 1: EMPLOYED WIVES' CONTRIBUTION TO FAMILY EARNINGS AND HUSBANDS' EMPLOYMENT BY STATE}

\begin{tabular}{|c|c|c|c|c|c|c|}
\hline \multirow[b]{3}{*}{ UNITED STATES } & \multicolumn{3}{|c|}{ EMPLOYED WIVES' CONTRIBUTION } & \multicolumn{3}{|c|}{ HUSBANDS' EMPLOYMENT } \\
\hline & $\begin{array}{c}\text { PRE- } \\
\text { RECESSION }\end{array}$ & RECESSION & $\begin{array}{c}\text { POST- } \\
\text { RECESSION }\end{array}$ & $\begin{array}{c}\text { PRE- } \\
\text { RECESSION }\end{array}$ & RECESSION & $\begin{array}{c}\text { POST- } \\
\text { RECESSION } \\
\end{array}$ \\
\hline & $44.0 \%$ & $45.4 \%^{a}$ & $47.2 \%^{b}$ & $90.9 \%$ & $89.9 \%^{a}$ & $88.2 \%^{b}$ \\
\hline NORTHEAST & $43.8 \%$ & $45.5 \%^{a}$ & $46.9 \%^{b}$ & $90.8 \%$ & $89.7 \%^{a}$ & $89.0 \%$ \\
\hline CONNECTICUT & $42.3 \%$ & $44.4 \%^{\mathrm{a}}$ & $46.0 \%$ & $92.5 \%$ & $91.4 \%$ & $90.4 \%$ \\
\hline MAINE & $43.5 \%$ & $46.6 \%^{a}$ & $47.9 \%$ & $91.4 \%$ & $89.7 \%$ & $88.3 \%$ \\
\hline MASSACHUSETTS & $43.5 \%$ & $45.6 \%$ & $44.6 \%$ & $90.4 \%$ & $88.3 \%$ & $90.7 \%$ \\
\hline NEW HAMPSHIRE & $42.5 \%$ & $44.2 \%^{a}$ & $45.3 \%$ & $92.0 \%$ & $92.0 \%$ & $91.3 \%$ \\
\hline NEW JERSEY & $41.7 \%$ & $45.0 \%{ }^{a}$ & $45.0 \%$ & $93.2 \%$ & $90.1 \%^{a}$ & $91.6 \%$ \\
\hline NEW YORK & $46.0 \%$ & $47.2 \%$ & $48.5 \%$ & $89.1 \%$ & $88.5 \%$ & $87.3 \%$ \\
\hline PENNSYLVANIA & $43.2 \%$ & $43.9 \%$ & $47.7 \%^{b}$ & $90.9 \%$ & $91.0 \%$ & $87.9 \%^{b}$ \\
\hline RHODE ISLAND & $44.0 \%$ & $46.1 \%$ & $47.0 \%$ & $90.3 \%$ & $88.5 \%$ & $89.6 \%$ \\
\hline VERMONT & $43.3 \%$ & $46.0 \%{ }^{a}$ & $45.8 \%$ & $92.1 \%$ & $90.6 \%$ & $91.4 \%$ \\
\hline MIDWEST & $43.2 \%$ & $45.0 \%^{a}$ & $46.6 \%^{b}$ & $91.6 \%$ & $90.9 \%$ & $88.6 \%^{b}$ \\
\hline ILLINOIS & $43.0 \%$ & $44.0 \%$ & $47.3 \%^{b}$ & $92.0 \%$ & $91.9 \%$ & $88.5 \%^{b}$ \\
\hline INDIANA & $43.7 \%$ & $46.9 \%^{a}$ & $47.9 \%$ & $91.5 \%$ & $89.9 \%$ & $85.7 \%^{b}$ \\
\hline IOWA & $42.1 \%$ & $43.8 \%$ & $44.3 \%$ & $93.8 \%$ & $92.7 \%$ & $90.4 \%^{b}$ \\
\hline KANSAS & $42.4 \%$ & $42.0 \%$ & $44.6 \%^{b}$ & $92.7 \%$ & $94.3 \%$ & $89.8 \%^{b}$ \\
\hline MICHIGAN & $43.5 \%$ & $46.3 \%^{a}$ & $48.4 \%^{b}$ & $89.3 \%$ & $88.3 \%$ & $85.4 \%^{b}$ \\
\hline MINNESOTA & $42.5 \%$ & $44.2 \%^{\mathrm{a}}$ & $44.6 \%$ & $93.4 \%$ & $92.3 \%$ & $92.2 \%$ \\
\hline MISSOURI & $44.7 \%$ & $46.4 \%$ & $47.0 \%$ & $89.7 \%$ & $88.8 \%$ & $87.3 \%$ \\
\hline NEBRASKA & $41.9 \%$ & $44.2 \%^{a}$ & $43.8 \%$ & $93.0 \%$ & $92.8 \%$ & $93.4 \%$ \\
\hline NORTH DAKOTA & $43.0 \%$ & $43.2 \%$ & $42.4 \%$ & $92.4 \%$ & $94.1 \%$ & $93.9 \%$ \\
\hline $\mathrm{OHIO}$ & $43.4 \%$ & $45.1 \%$ & $46.0 \%$ & $91.7 \%$ & $89.9 \%$ & $89.0 \%$ \\
\hline SOUTH DAKOTA & $43.3 \%$ & $43.5 \%$ & $43.6 \%$ & $93.8 \%$ & $93.4 \%$ & $93.2 \%$ \\
\hline WISCONSIN & $43.1 \%$ & $45.0 \%{ }^{a}$ & $47.7 \%^{b}$ & $92.1 \%$ & $92.8 \%$ & $88.8 \%^{b}$ \\
\hline SOUTH & $45.0 \%$ & $45.8 \%^{a}$ & $47.7 \%^{b}$ & $90.0 \%$ & $89.4 \%^{a}$ & $87.6 \%^{b}$ \\
\hline ALABAMA & $45.6 \%$ & $44.8 \%$ & $47.5 \%$ & $88.2 \%$ & $88.1 \%$ & $86.3 \%$ \\
\hline ARKANSAS & $45.9 \%$ & $47.5 \%$ & $49.5 \%$ & $89.2 \%$ & $88.1 \%$ & $85.5 \%$ \\
\hline DELAWARE & $45.1 \%$ & $45.8 \%$ & $48.3 \%^{b}$ & $89.9 \%$ & $90.0 \%$ & $87.6 \%$ \\
\hline DISTRICT OF COLUMBIA & $47.3 \%$ & $47.4 \%$ & $49.3 \%$ & $90.7 \%$ & $89.3 \%$ & $90.9 \%$ \\
\hline FLORIDA & $46.4 \%$ & $48.5 \%^{a}$ & $50.5 \%{ }^{b}$ & $90.2 \%$ & $87.1 \%^{a}$ & $84.6 \%^{b}$ \\
\hline GEORGIA & $45.9 \%$ & $44.8 \%$ & $48.6 \%^{b}$ & $89.6 \%$ & $91.1 \%$ & $87.4 \%^{b}$ \\
\hline KENTUCKY & $45.8 \%$ & $47.2 \%$ & $48.6 \%$ & $88.3 \%$ & $87.0 \%$ & $86.5 \%$ \\
\hline LOUISIANA & $44.2 \%$ & $42.1 \%$ & $48.3 \%^{b}$ & $90.2 \%$ & $90.7 \%$ & $85.7 \%^{b}$ \\
\hline MARYLAND & $44.6 \%$ & $45.5 \%$ & $47.9 \%^{b}$ & $91.5 \%$ & $92.2 \%$ & $88.1 \%^{b}$ \\
\hline MISSISSIPPI & $47.3 \%$ & $47.0 \%$ & $46.4 \%$ & $86.0 \%$ & $87.7 \%$ & $89.9 \%$ \\
\hline NORTH CAROLINA & $45.1 \%$ & $47.3 \%^{a}$ & $48.5 \%$ & $90.5 \%$ & $89.1 \%$ & $87.7 \%$ \\
\hline OKLAHOMA & $45.2 \%$ & $44.3 \%$ & $43.7 \%$ & $89.9 \%$ & $90.5 \%$ & $89.4 \%$ \\
\hline SOUTH CAROLINA & $43.2 \%$ & $46.9 \%^{a}$ & $49.3 \%$ & $90.3 \%$ & $87.3 \%^{a}$ & $85.7 \%$ \\
\hline TENNESSEE & $45.6 \%$ & $47.0 \%$ & $48.2 \%$ & $87.7 \%$ & $87.0 \%$ & $86.3 \%$ \\
\hline TEXAS & $43.3 \%$ & $44.1 \%$ & $45.0 \%$ & $91.8 \%$ & $91.0 \%$ & $90.2 \%$ \\
\hline VIRGINIA & $43.6 \%$ & $43.3 \%$ & $46.0 \%^{b}$ & $90.9 \%$ & $91.8 \%$ & $89.9 \%$ \\
\hline WEST VIRGINIA & $49.5 \%$ & $48.9 \%$ & $50.1 \%$ & $82.0 \%$ & $83.7 \%$ & $83.1 \%$ \\
\hline WEST & $43.5 \%$ & $45.0 \%^{\mathrm{a}}$ & $47.4 \% \%^{b}$ & $91.3 \%$ & $89.9 \%{ }^{a}$ & $88.0 \%{ }^{b}$ \\
\hline ALASKA & $42.3 \%$ & $43.5 \%$ & $44.9 \%$ & $92.4 \%$ & $92.8 \%$ & $89.7 \%^{b}$ \\
\hline ARIZONA & $44.9 \%$ & $48.0 \%^{a}$ & $48.2 \%$ & $88.7 \%$ & $86.1 \%$ & $87.4 \%^{b}$ \\
\hline CALIFORNIA & $44.2 \%$ & $45.7 \%^{a}$ & $48.7 \%^{b}$ & $91.3 \%$ & $89.9 \%^{a}$ & $87.3 \%$ \\
\hline COLORADO & $42.3 \%$ & $43.6 \%$ & $45.3 \%$ & $93.8 \%$ & $91.7 \%^{a}$ & $90.6 \%$ \\
\hline HAWAll & $46.0 \%$ & $45.4 \%$ & $49.4 \%^{b}$ & $89.7 \%$ & $90.4 \%$ & $86.7 \%^{b}$ \\
\hline IDAHO & $41.1 \%$ & $42.4 \%$ & $42.6 \%$ & $92.2 \%$ & $91.0 \%$ & $91.1 \%$ \\
\hline MONTANA & $41.9 \%$ & $43.8 \%$ & $45.5 \%$ & $92.4 \%$ & $90.6 \%$ & $91.3 \%$ \\
\hline NEVADA & $44.8 \%$ & $47.2 \%^{a}$ & $49.8 \%^{b}$ & $90.3 \%$ & $88.1 \%$ & $85.8 \%$ \\
\hline NEW MEXICO & $45.9 \%$ & $45.3 \%$ & $48.4 \%$ & $87.9 \%$ & $87.4 \%$ & $87.2 \%$ \\
\hline OREGON & $44.1 \%$ & $44.4 \%$ & $48.1 \%^{b}$ & $89.8 \%$ & $90.7 \%$ & $86.7 \%^{b}$ \\
\hline UTAH & $35.9 \%$ & $39.2 \%^{a}$ & $40.6 \%$ & $95.9 \%$ & $92.6 \%^{a}$ & $93.0 \%$ \\
\hline WASHINGTON & $42.4 \%$ & $44.1 \%$ & $45.6 \%$ & $91.6 \%$ & $90.3 \%$ & $87.4 \%^{b}$ \\
\hline WYOMING & $39.5 \%$ & $40.3 \%$ & $40.9 \%$ & $92.8 \%$ & $93.5 \%$ & $92.9 \%$ \\
\hline
\end{tabular}

Notes: 1) Wives are between 18 and 64 years of age. 2) a Indicates a statistically significant difference from pre-recession to recession period; ${ }^{b}$ indicates a statistically significant difference from recession to post-recession period. Source: Current Population Survey: ASEC, 2005-2013
Whereas nationally wives' share of family earnings increased during the recession and held steady since, the trends for states have not been uniform. In seventeen states, employed wives' contribution to family earnings increased between the pre-recession and recession period, and in thirty-two states, wives' contribution did not change (see Table 1). In South Carolina, the state that experienced the largest decrease in employment rates among husbands of employed wives during this period, we also see the largest increase (3.7 percentage point increase) in employed wives' share of family earnings. In general, states that experienced large decreases in husbands' employment also experienced increases in wives' share of family earnings. From the pre- to post-recession period, however, Maine, Vermont, and Arizona experienced substantial increases in employed wives' share of family earnings without a corresponding statistically significant decrease in the employment rates of husbands.

After the recession, employed wives' share held steady in thirtyfour states, but it increased further in fifteen states and decreased in no states. Some states, such as Louisiana, Nebraska, Georgia, and Pennsylvania, experienced substantial increases in employed wives' share of family earnings after the recession. Other states, such as Maine, New Hampshire, Vermont, and Minnesota, experienced increases in the pre-recession to recession period but remained steady in the recession to postrecession period. Louisiana experienced the largest increase $(6.2$ percentage points) in employed wives' contribution during the post-recession period. 
Figure 3 presents the change in employed wives' contribution to family earnings between the prerecession and post-recession periods. Only thirteen states experienced no statistically significant change in employed wives' contribution to family earnings during this period. No states experienced a decrease in employed wives' share and thirtyseven states experienced statistically significant increases. Of those thirtyseven states, fourteen experienced substantial increases of more than 2.5 percentage points. During this period, South Carolina experienced the largest increase (6.1 percentage points) in employed wives' share.

In addition to changes in wives' contribution to family earnings during the pre- to post-recession period, many states also experienced shifts in median family earnings. Of the states that experienced decreases of more than $\$ 2,000$ in median family earnings, twelve states experienced losses greater than $\$ 4,000$ (see Figure 4). Among those twelve states with the largest losses in family earnings are Nevada, Wisconsin, and Florida, states that also experienced substantial increases in wives' share of family earnings (and large decreases in husbands' employment and therefore earnings). Other states that experienced large decreases in median family earnings, such as Idaho and Alabama, did not see corresponding increases in wives' share of family earnings. It appears that states that experienced increases of more than $\$ 2,000$ in family earnings also experienced few changes in wives' contributions. Indeed, of the five states that experienced the largest increases in family earnings in the pre- to post-recession period (North Dakota, Nebraska,

\section{FIGURE 3: CHANGE IN EMPLOYED WIVES' CONTRIBUTION TO FAMILY EARNINGS FROM PRE-RECESSION TO POST-RECESSION TIME PERIOD}

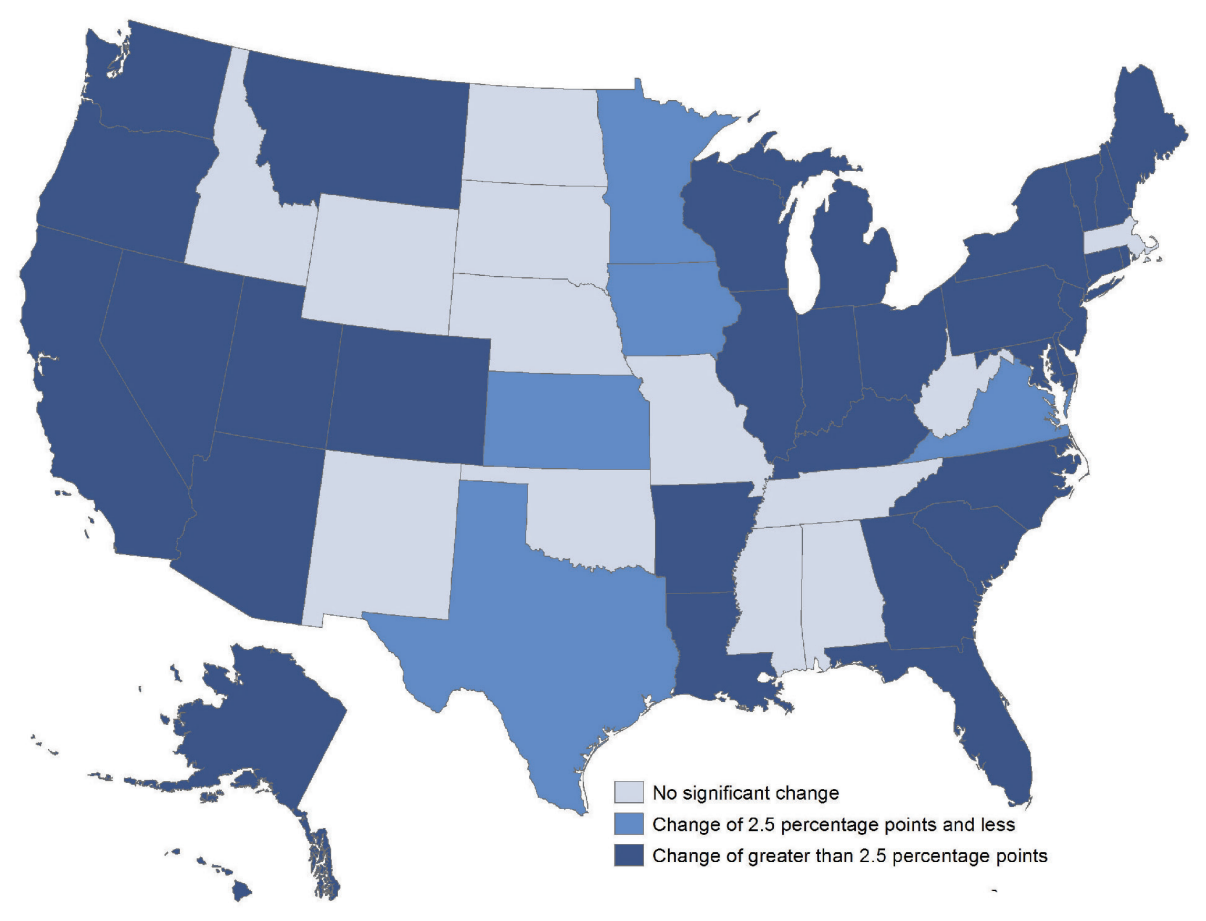

Source: Current Population Survey: ASEC, 2005-2013

\section{FIGURE 4: CHANGE IN MEDIAN FAMILY EARNINGS FROM PRE-RECESSION TO POST-RECESSION TIME PERIOD (IN CONSTANT 2012 DOLLARS)}

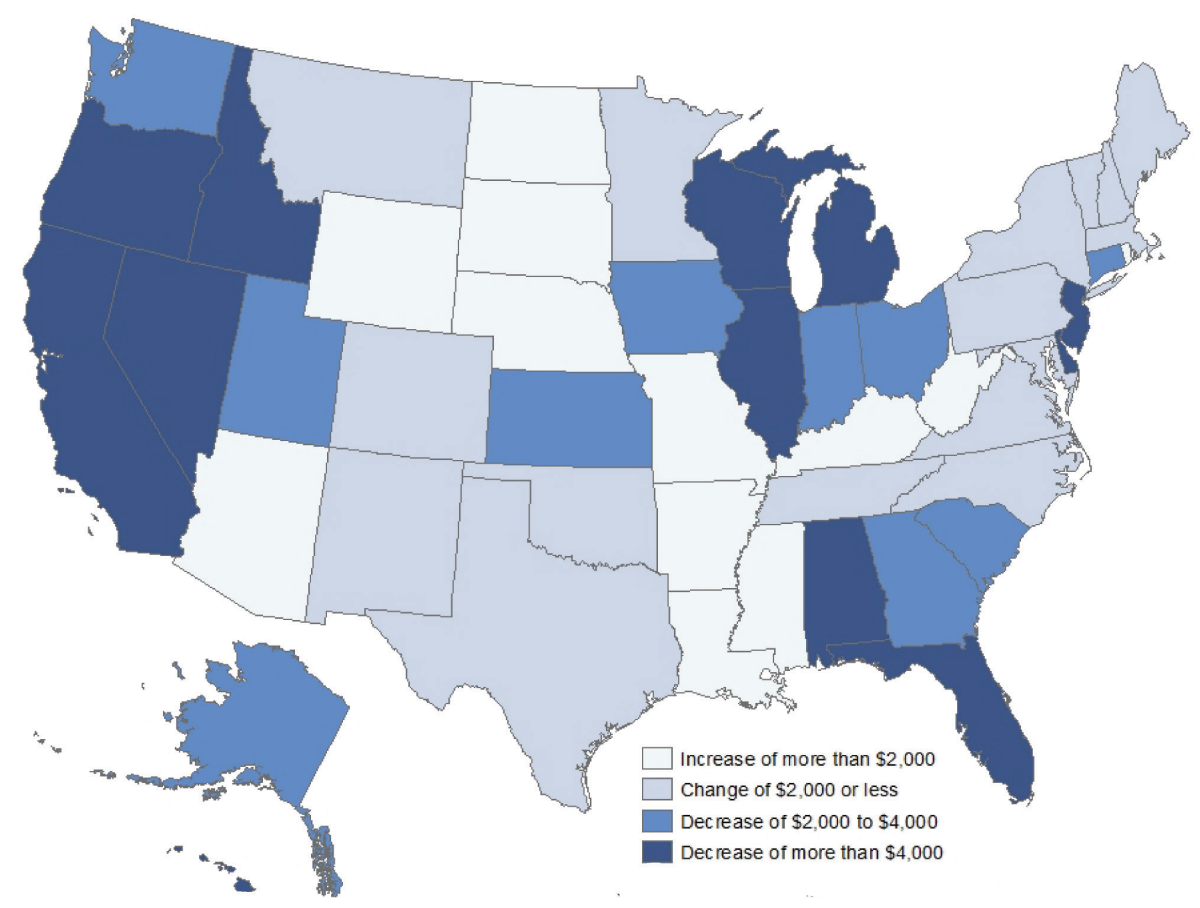

Source: Current Population Survey: ASEC, 2005-2013 
Wyoming, Mississippi, and Rhode Island), only Rhode Island experienced a significant increase in wives' contribution during the same years and all five states experienced steady or increased employment rates among husbands.

\section{Regional Variation in Wives' Contribution to Family Earnings}

We present data for each year rather than grouped in the three periods for this section because regional data allow for more nuanced analyses. Employed wives in the South contributed more to family earnings than their counterparts in other regions in 2004, but by 2012 employed wives in all regions contributed similarly, at approximately 47 percent (see Figure 5). The largest increase in employed wives' contribution to family earnings occurred in the Midwest between 2004 and 2012. In 2004, prior to the Great Recession, employed wives living in the Midwest contributed approximately 43 percent of family earnings. This percentage increased during the recession and continued to increase during the post-recession period to 47 percent in 2012 .

In combination, Figure 5 and Figure 6 clearly show the inverse relationship between husbands' employment rates and wives' contribution to family earnings. In all four regions of the United States, as husbands lost jobs during the Great Recession, employed wives' contribution to family earnings increased. This was because of the reduction in husbands' earnings, in addition to employed wives increasing their work hours and nonemployed wives entering

\section{FIGURE 5: EMPLOYED WIVES' CONTRIBUTION TO FAMILY EARNINGS BY REGION, 2004-2012}

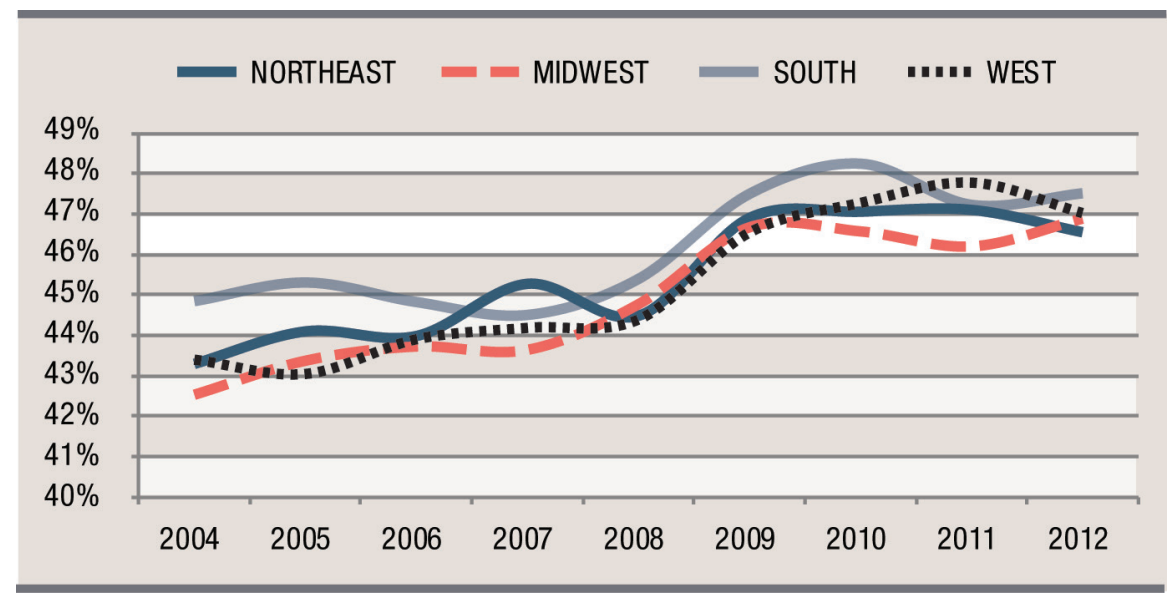

Note: Wives are between 18 and 64 years of age. Source: Current Population Survey: ASEC, 2005-2013

\section{FIGURE 6: HUSBAND'S EMPLOYMENT AMONG EMPLOYED WIVES BY} REGION, 2004-2012

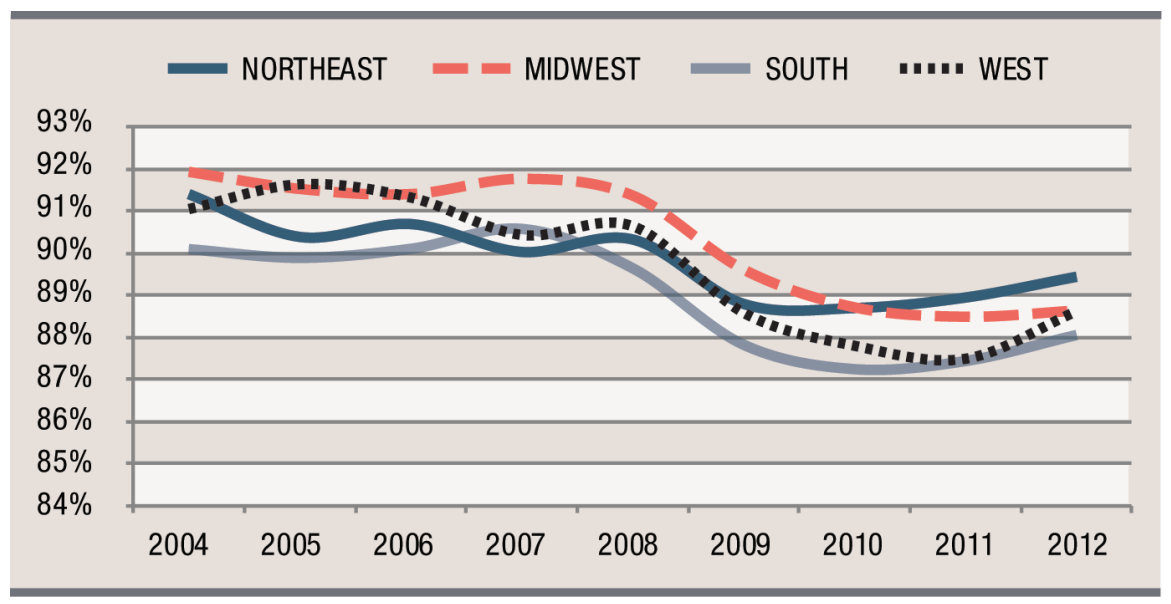

Note: Wives are between 18 and 64 years of age. Source: Current Population Survey: ASEC, 2005-2013

the paid workforce. We also see in Figure 5 and Figure 6 that the effects of the Great Recession were not isolated to one region of the United States, but rather husbands lost jobs in all regions and wives' contribution to family earnings increased in all regions. Since the end of the recession in 2009, husbands' employment has increased most notably in the Northeast, signaling job gains and a potential turnaround for this region. In addition, husbands' employment did not decrease as much in the Northeast as it did in other regions. However, by 2012, this had not translated into a statistically significant decrease in employed wives' share of family earnings, as it has held steady at approximately 47 percent since 2009. 


\section{Nonmetro and Metro Employed Wives' Contribution Converges During Recession}

We also see substantial differences in employed wives' share of family earnings by place type. Between 2004 and 2007, employed wives in metropolitan areas contributed statistically significantly less to family earnings than their nonmetropolitan counterparts, as shown in Figure 7. For instance, in 2004, employed wives in metropolitan areas contributed 43 percent to family earnings compared with 45 percent of employed wives in nonmetropolitan places. These differences remained steady until 2008 when employed wives' contribution to family earnings in metropolitan and nonmetropolitan areas converged. Although the gaps between employed wives in metropolitan and nonmetropolitan areas converged through the recession, in both of these areas, employed wives' share increased. Furthermore, as in the states, increases in employed wives' contribution to family earnings in the metropolitan and nonmetropolitan areas corresponded with decreases in husbands' employment rates.

\section{Wives' Share of Family Earnings in the Largest Metropolitan Areas}

By focusing on the largest fifteen metropolitan areas, ${ }^{12}$ we are able to consider wives' contribution to family earnings in specific labor markets. In areas where husbands' job loss was minimal during the Great Recession, such as in Dallas and Seattle, wives' share of family earnings remained the same during the three periods (see Figure 8 and Figure 9 on the next page).

\section{FIGURE 7: EMPLOYED WIVES' CONTRIBUTION TO FAMILY EARNINGS BY METROPOLITAN STATUS, 2004-2012}

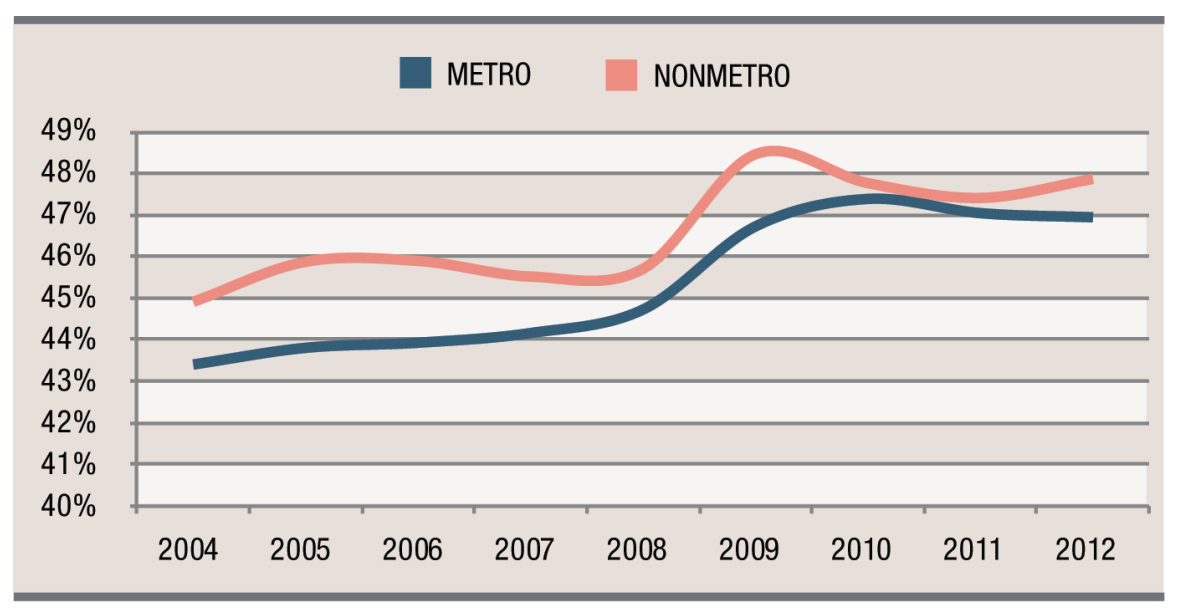

Note: Wives are between 18 and 64 years of age. Source: Current Population Survey: ASEC, 2005-2013

In contrast, in metropolitan areas where there was a large decrease in husbands' employment, wives' share of family earnings increased to a greater extent. For example, in Riverside, wives' contribution increased during the post-recession period and husbands' employment rates decreased. Not all metropolitan areas follow this pattern, however. For instance, in Detroit, wives' contribution to family earnings decreased post-recession, despite continued job loss among men.

\section{Implications of Increased Reliance on Wives as Breadwinners}

National employment trends paint a picture of slow recovery in the postrecession United States. Although the economy has improved during the post-recession period, national unemployment rates remain higher than those during pre-recession, and the share of the long-term unemployed remains stubbornly high. ${ }^{13}$ Furthermore, the proportion of those working part-time involuntarily (that is, those working part-time when they would prefer full-time) increased during the recession for both men and women. ${ }^{14}$ One outcome of these trends for families is an increased reliance on wives' earnings to make ends meet. ${ }^{15}$

These national trends mask patterns at lower levels of geography. In this brief, we document trends in wives' contribution to family earnings by state, region, and metropolitan areas, focusing on change during the Great Recession. We find that wives' share of family earnings increased in most of the states from the pre-recession to the post-recession period, but not all of them. Similarly, with few exceptions, the states where husbands' employment rates decreased the most during the recession also experienced the largest increases in wives' share of family earnings. In general, decreases in median family earnings from the pre- to postrecession period coincided with the states that experienced high 


\section{FIGURE 8: EMPLOYED WIVES' CONTRIBUTION TO FAMILY EARNINGS BY METROPOLITAN AREA, 2004-2012}

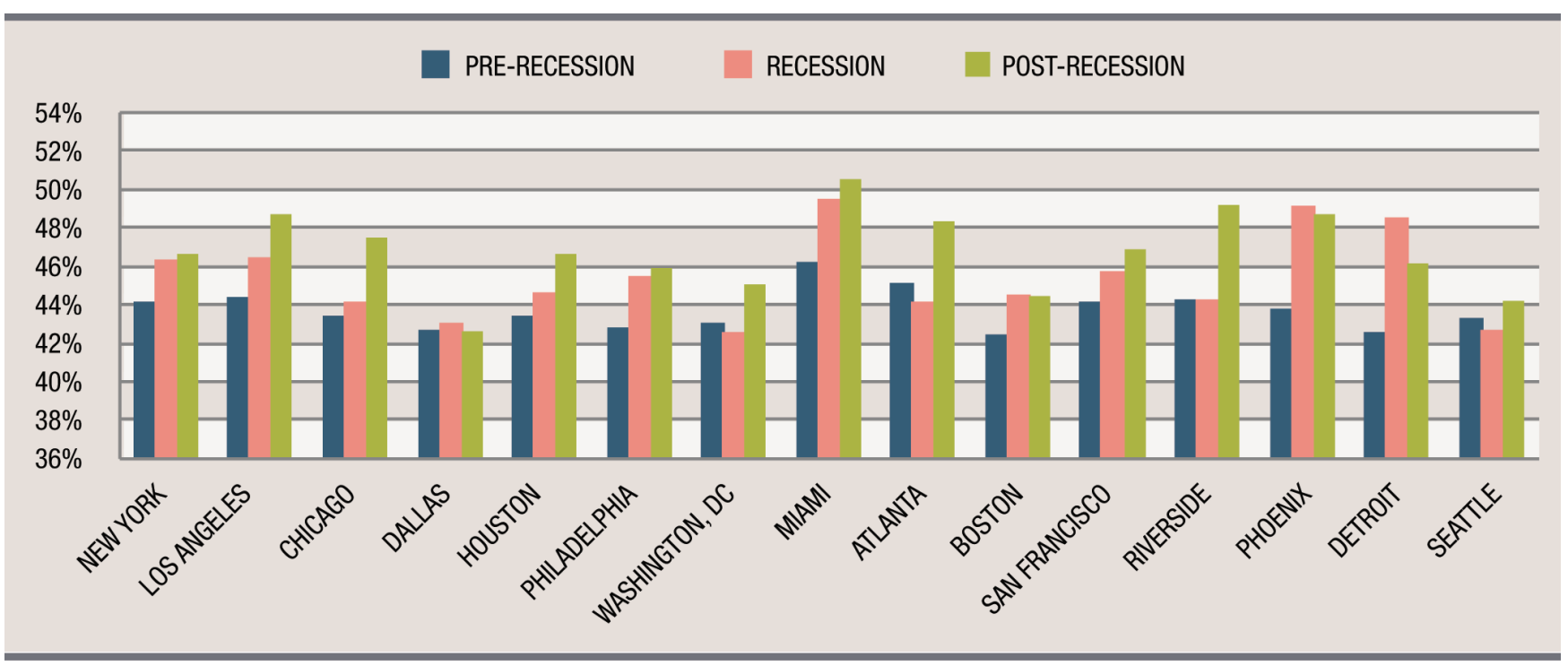

Note: Wives are between 18 and 64 years of age. Source: Current Population Survey: ASEC, 2005-2013

FIGURE 9: HUSBAND'S EMPLOYMENT AMONG EMPLOYED WIVES BY METROPOLITAN AREA, 2004-2012

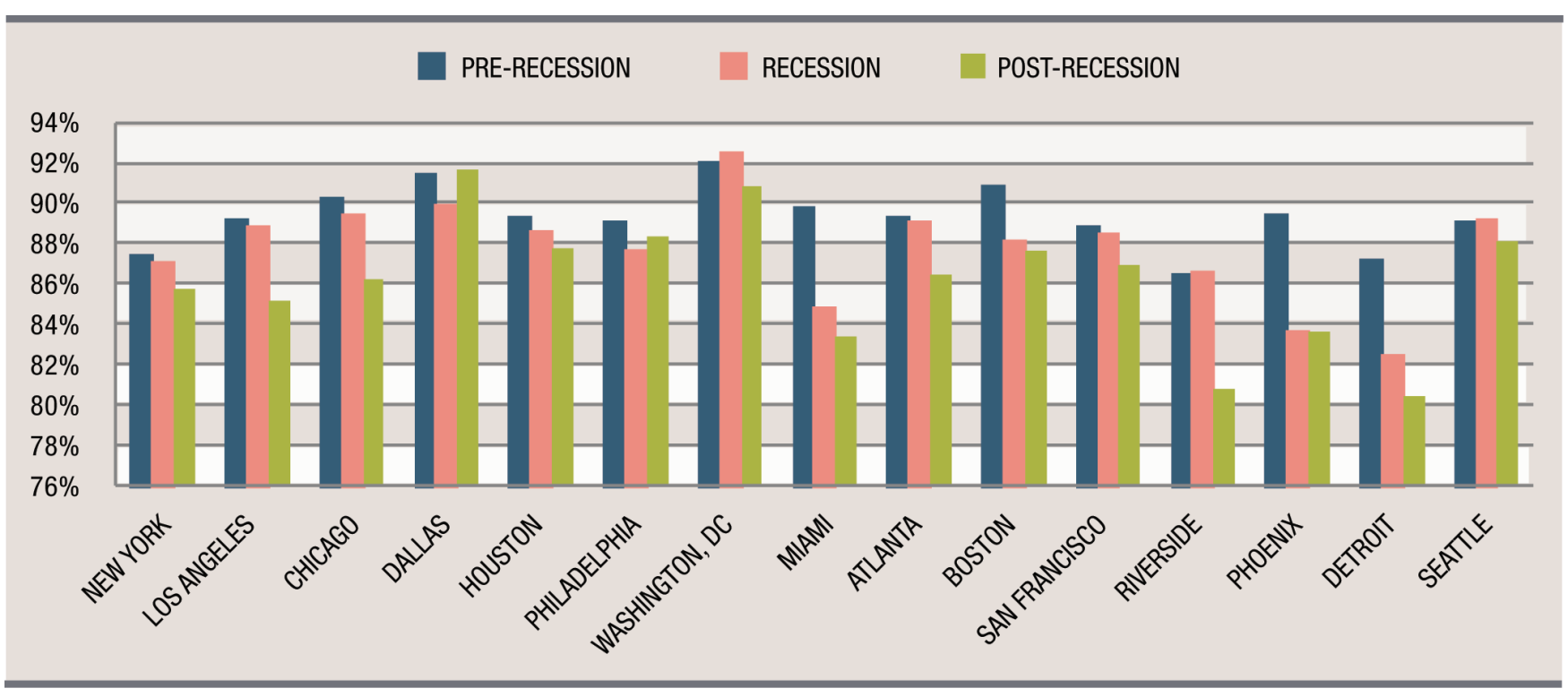

Note: Wives are between 18 and 64 years of age. Source: Current Population Survey: ASEC, 2005-2013 
job loss among husbands and increases in wives' share of family earnings. Some possible other sources of variation by state include differences in state policies, major industries, and statewide demographics. More nuanced research linking variation in state-specific factors is needed to better understand the implications of the Great Recession on wives' contribution to family economic well-being.

In the wake of the Great Recession, median family earnings remain depressed in many states leading to increased stress and continued unease for families, despite increased reliance on wives' earnings. Our results highlight the continued need to support working families on the federal and state levels. With families relying more on wives as breadwinners, policies that increase wives' paychecks and provide support to working families are critical. As women are more likely to be in minimum wage jobs, policies that increase the minimum wage will help families in the aftermath of the Great Recession. Furthermore, paid sick leave and paid family medical leave are important workplace policies as more families rely on two breadwinners.

\section{Data}

The data in this brief come from the 1989-2013 Annual Social and Economic Supplements (ASEC) of the Current Population Survey (CPS). The CPS is a joint project between the Bureau of Labor Statistics and the U.S. Census Bureau to measure national unemployment. The ASEC supplements analyzed here are conducted in March of each year and are obtained from the IPUMS files compiled by the Minnesota Population Center. Questions about earnings and income refer to the previous year. For example, "wives' contribution to family earnings" for 2012 is wives' annual earnings as a proportion of family earnings collected in the 2013 ASEC. All analyses are weighted using person level weights provided by the Census Bureau. Differences presented in the text are statistically significant $(p<.05)$.
The Current Population Survey uses the Office of Management and Budget classification of metropolitan areas defined as: (1) a central county (or counties) containing at least one urbanized area with a population of at least 50,000 people, and (2) the counties that are socially and economically integrated with the urbanized area, as measured by commuting patterns. All other areas are nonmetropolitan.

\section{End notes}

1. Although the Great Recession officially ended in June 2009, job loss continued into January 2010.

2. Authors' calculations use U.S. Bureau of Labor Statistics, Employment, Hours, and Earnings from the Current Employment Statistics Survey (National), Table CES0000000001 (Washington, DC: U.S. Bureau of Labor Statistics, 2014).

3. Bureau of Labor Statistics, Employment Situation Summary (Washington, DC: U.S. Bureau of Labor Statistics, 2014), available at www.bls.gov/news.release/empsit.nr0.htm.

4. Rebecca Glauber, "Wanting More but Working Less: Involuntary Part-Time Employment and Economic Vulnerability," Issue brief No. 64 (Durham, NH: Carsey Institute, University of New Hampshire, 2012).

5. Carmen DeNavas-Walt, Bernadette Proctor, and Jessica Smith, "Income, Poverty, and Health Insurance Coverage in the United States: 2012" (Washington, DC: U.S. Census Bureau, 2013).

6. Bureau of Labor Statistics, "Economic and Employment Data" (Washington, DC: U.S. Bureau of Labor Statistics, 2012), available at www.bls.gov/data/\#unemployment.

7. U.S. Bureau of Labor Statistics, Employment Situation Summary.

8. Marybeth Mattingly and Kristin Smith, "Changes in Wives' Employment When Husbands Stop Working: A RecessionProsperity Comparison," Family Relations, vol. 59 (2010): 343-357.

9. Ibid.

10. Ibid.

11. Kristin Smith, "Increased Role of Wives as Breadwinners, 1978-2012" (paper presented at the 2013 American Sociological Association, New York, New York, 2013). 
12. As of the 2010 Census, the fifteen largest metropolitan statistical areas are (1) New York, Newark, New Jersey; (2) Los Angeles, Long Beach, Anaheim; (3) Chicago, Naperville, Elgin; (4) Dallas, Fort Worth, Arlington; (5) Houston, the Woodlands, Sugarland; (6) Philadelphia, Camden, Wilmington; (7) Washington, Arlington, Alexandria; (8) Miami, Fort Lauderdale, West Palm Beach; (9) Atlanta, Sandy Springs, Roswell; (10) Boston, Cambridge, Newton; (11) San Francisco, Oakland, Fremont; (12) Phoenix, Mesa, Scottsdale; (13) Riverside, San Bernardino, Ontario; (14) Detroit, Warren, Dearborn; and (15) Seattle, Tacoma, Bellevue.

13. Andrew Schaefer, "The Long-Term Unemployed in the Wake of the Great Recession," Issue brief No. 68 (Durham, NH: Carsey Institute, University of New Hampshire, 2012).

14. Rebecca Glauber, "Wanting More but Working Less."

15. Kristin Smith, "Recessions Accelerate Trend of Wives as Breadwinners," Issue brief No. 56 (Durham, NH: Carsey Institute, University of New Hampshire, 2012).

\section{ABOUT THE AUTHORS}

Kristin Smith is a family demographer at the Carsey School of Public Policy and research assistant professor of sociology at the University of New Hampshire (kristin.smith@unh.edu).

Andrew Schaefer is a doctoral student in sociology at the University of New Hampshire and research assistant at the Carsey School of Public Policy (apq62@ wildcats.unh.edu).

\section{A C K N O W LE D G M ENTS}

The authors thank Michael Ettlinger, Marybeth Mattingly, Curt Grimm, Amy Sterndale, Laurel Lloyd, and Barbara Cook at the Carsey School of Public Policy; Ann Tickamyer, professor of sociology at the Pennsylvania State University; Debbie Stein, vice president of policy at the Hatcher Group; and Barbara Ray at Hired Pen for their assistance, comments, and suggestions.

\section{TI University of New Hampshire Carsey School of Public Policy}

The Carsey School of Public Policy conducts policy research on vulnerable children, youth, and families and on sustainable community development. We give policy makers and practitioners timely, independent resources to effect change in their communities.

This work was supported by the Annie E. Casey Foundation, the W. K. Kellogg Foundation, and anonymous donors.

Huddleston Hall • 73 Main Street • Durham, NH 03824

(603) 862-2821

TTY UsERS: DIAL 7-1-1 OR 1-800-735-2964 (RELAY N.H.)

carsey.unh.edu 